\title{
Climate, radial growth, and mortality associated with conifer regeneration infected by root disease (Armillaria ostoyae)
}

\author{
By Michael P. Murray ${ }^{1}$ and Adrian Leslie ${ }^{2}$
}

\begin{abstract}
Tree root disease caused by the pathogen Armillaria ostoyae (Romagn.) Herink has notable influence on bio-economic systems of southern British Columbia (BC) and the northwestern United States. Annual radial growth and mortality trends of regeneration associated with A. ostoyae during the first 21 years of a plantation were investigated. Our dendrochronological approach focused on a plantation established in 1991 with Douglas-fir (Pseudotsuga menziesii (Mirb.) Franco), western larch (Larix occidentalis Nutt.), and lodgepole pine (Pinus contorta Dougl. ex Loud. var. latifolia Engelm. ex S. Wats.). We examined tree rings for reduced growth onset (RGO) to estimate infection periods. Among trees studied, we found that the number of RGO events peaked in 2006 followed by a steady decline in frequency. A similar trend was seen in annual mortality rates which reached maximum values in 2007 followed by an uninterrupted decrease. The average number of years from RGO to death based on host species ranged from 2.3 to 3.6 years. According to logistic regression modeling, values associated with drought codes and duff moisture codes were significant in determining the year of death for infected trees. The predicted increase in frequency of summer droughts may lead to elevated mortality associated with A. ostoyae in young plantations.
\end{abstract}

Keywords: Armillaria ostoyae, conifer regeneration, annual growth, tree mortality, plantation, drought, weather.

\section{RÉSUMÉ}

Le pourridié causé par le pathogène Armillaria ostoyae (Romagn.) Herink nuit grandement aux systèmes bioéconomiques du sud de la Colombie-Britannique et du nord-ouest des États-Unis. Cette étude s'intéresse à l'effet d'A. ostoyae sur la croissance annuelle radiale et la mortalité de la régénération au cours des 21 premières années d'une plantation. Notre approche dendrochronologique a porté sur une plantation de 1991 constituée de sapin Douglas (Pseudotsuga menziesii (Mirb.) Franco), de mélèze de l'Ouest (Larix occidentalis Nutt.) et de pin Lodgepole pine (Pinus contorta Dougl. ex Loud. var. latifolia Engelm. ex S. Wats.). À partir des anneaux de croissance, nous avons cherché à établir le début de la réduction de croissance (RGO) pour estimer la période d'infection. Sur les arbres étudiés, nous avons constaté que le nombre de cas de réduction de croissance (RGO) culminait en 2006 et déclinait régulièrement par la suite. La même tendance s'est manifestée avec le de mortalité annuelle qui a atteint son maximum en 2007 avant de diminuer constamment par la suite. Le nombre moyen d'années entre l'amorce de la diminution de croissance (RGO) et la mort variait de 2,3 à 3,6 ans suivant l'essence de l'arbre-hôte. La modélisation par régression logistique a montré que les valeurs des indices de sécheresse et d'humidité de l'humus influençaient significativement la prédiction du moment de la mortalité chez les arbres infectés. Les épisodes de sécheresse de plus en plus fréquents qu'on nous annonce risquent d'accroître la mortalité associée à A. ostoyae dans les jeunes plantations.

Mots-clés: Armillaria ostoyae, régénération des conifères, croissance annuelle, mortalité des arbres, plantation, sécheresse, météo.

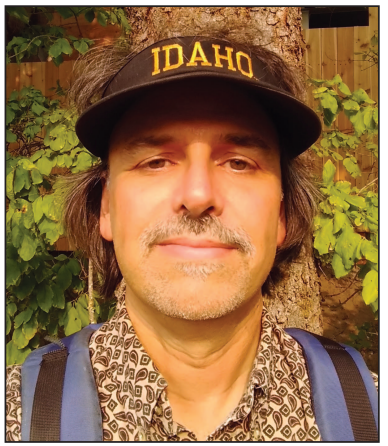

Michael P. Murray

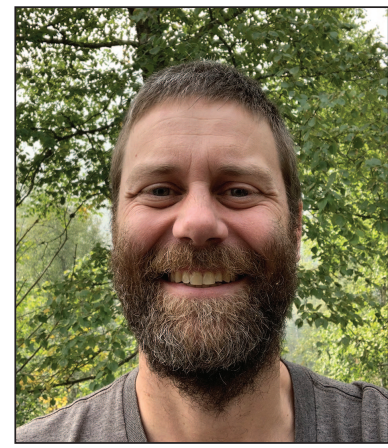

Adrian Leslie

\section{Introduction}

The tree root disease caused by the pathogen Armillaria ostoyae (Romagn.) Herink has notable influence on ecological and economic systems of southern British Columbia (BC) and the northwestern United States. In unmanaged forests where A. ostoyae is endemic, it plays an important role in forest ecosystems through its ability to weaken or kill trees, and contribute to stand structure, forest succession, decomposition, and nutrient cycling processes (Edmonds et al. 2010). In stands of the Interior Cedar Hemlock (ICH) forests of southern BC, up to $100 \%$ of mature trees can be infected with $A$. ostoyae (Morrison et al. 2001). Young trees are also suscepti-

\footnotetext{
${ }^{1}$ British Columbia Ministry of Forests, Lands, Natural Resource Operations and Rural Development, \#401-333 Victoria Street, Nelson, BC V1L 4K3, Canada, email: Michael.Murray@gov.bc.ca

${ }^{2}$ White Bark Consulting, Castlegar, BC V1N 4T5, Canada
} 
ble with post-harvest regeneration losses of up to $2 \%$ per year in plantations (Peet et al. 1996; Morrison et al. 2014).

The economic importance of $A$. ostoyae is closely tied to timber production. This disease impacts sustainable forest management due to its ability to increase following harvest, reduce tree growth rates, and cause mortality, especially in young regeneration (Cruickshank 2000; Morrison 2000). The earliest stages of plantation development are especially vulnerable due to the tendency for $A$. ostoyae to cause high mortality rates during the first 5-20 years of a rotation (Morrison et al. 1988; Morrison and Pellow 1994). This is a reflection of A. ostoyae readily colonizing freshly cut stumps and their roots plus lower resistance inherent in very young trees (Cleary et al. 2008). This pathogen spreads primarily through root-to-root contact and rhizomorphs that extend from established infections. Morrison (2011) found that seedlings were infected most frequently by rhizomorphs and root-toroot contact with old stumps. After 15-21 years, the importance of rhizomorphs declined compared to stumps. More information regarding spread and mortality within young plantations can be useful for guiding reforestation practices. The Province of $\mathrm{BC}$ mandates that every harvest unit receive a post-planting survey to ensure that reforestation of the site achieves appropriate stocking levels (BC FRPA 2004). Plantations that are declared as meeting the mandated stocking levels during this survey are not usually inspected again prior to harvest age (ca. $60-80$ years). In areas prone to root disease, surveys would be most useful if timed to occur after any anticipated period of highest mortality.

Several field trials have quantified the temporal progression of A. ostoyae within young plantations in the southern interior of BC. Researchers have applied varying combinations of field methods for detecting and documenting mortality and infection including observing above-ground symptoms and signs such as mycelial evidence beneath bark (Morrison et al. 1988; Chapman et al. 2011; Morrison 2011). Morrison and Pellow (1994) examined Douglas-fir (Pseudotsuga menziesii (Mirb.) Franco) tree rings on root collar crosssections to estimate dates of deaths but not onset years of associated infections. Field sampling associated with these studies occurred at 2-10 year intervals spanning 11-35 year periods. We are unaware of any plantation studies estimating dates of both the infection periods and subsequent deaths using an annual resolution.

The interaction of $A$. ostoyae root disease and climate within young plantations is poorly understood. Mycelia of A. ostoyae physically disrupt tree vascular systems and can kill portions of root networks or result in host mortality. Reduced growth in diameter and height manifests as trees experience infection stress (Shaw and Kile 1991). Due to rising annual temperatures and more frequent and severe droughts, infected trees may have an amplified risk of mortality (Dukes et al. 2009; Kliejunas 2011). Assessing incidence (infection and mortality) of $A$. ostoyae on a yearly resolution may contribute to a level of understanding gained from similar studies that employed coarser, multi-year sampling frequencies (e.g., Morrison and Pellow 1994; Peet et al. 1996). Moreover, annual deaths can be compared with corresponding yearly weather variables to investigate potential relationships. In this study we examined tree ring growth to estimate infection and death trends of regeneration associated with
A. ostoyae during the first 21 years of a plantation. Our dendrochronological approach focused on the three tree species most commonly planted on harvested sites in the southern interior of BC: Douglas-fir, western larch (Larix occidentalis Nutt.), and lodgepole pine (Pinus contorta Dougl. ex Loud. var. latifolia Engelm. ex S. Wats.). We also assessed potential weather variables, which may affect both radial growth and the timing of death.

\section{Material and methods Study area}

In 1988, an A. ostoyae root disease research trial was established approximately $46 \mathrm{~km}$ north of Grand Forks, BC which is located on the border of Washington State, USA (Fig. 1a). The study area $\left(49^{\circ} 24^{\prime} 10^{\prime \prime} \mathrm{N}, 118^{\circ} 26^{\prime} 00^{\prime \prime} \mathrm{W}\right)$ is on the east side of Burrell Creek at an elevation range of $667-725 \mathrm{~m}$. The research trial is characterized by undulating terrain, slopes ranging from flat to $35 \%$ and various aspects. The average slope is $12 \%$, and average aspect is $255^{\circ}$. It is located in the Interior Cedar-Hemlock biogeoclimatic zone's very dry warm subzone (ICHxw) where summers average $15-30 \mathrm{~cm}$ precipitation and winters are very mild with little snowfall (MacKillop and Ehman 2016). The soil moisture regime ranges from subxeric at the steeper sites with shallow soils to mesic sites that are flat and with deeper soils. The research trial consists of a 40.8 ha plantation formerly dominated by lodgepole pine and larch. In 1988 and 1989 all merchantable trees were harvested. Replanting occurred with larch and lodgepole pine in 1991. The site was fill planted in 1995 with lodgepole pine in areas where cattle and rodent damage had occurred and naturally regenerated Douglas-fir became common throughout the site. The combined average density of these three species was 1600 stems per hectare. There are insignificant numbers of naturally regenerated western redcedar (Thuja plicata Donn ex D. Don) and western white pine (Pinus monticola Douglas ex D. Don). We collected fungal tissue from the basal portion of a lodgepole pine and submitted to the BC Plant Diagnostic Lab (Ministry of Agriculture). As A. ostoyae has been historically sampled here (Siltech 1989), we confirmed our identification using a polymerase chain reaction (PCR) test coupled with sequencing (Ross-Davis et al. 2012).

\section{Field methods}

In 1997, twenty fixed-area square plots (31.6 m x $31.6 \mathrm{~m}$ ) were randomly positioned throughout the research trial area. Within each plot, all trees were located on $\mathrm{X}-\mathrm{Y}$ axes, mapped, and tagged (3219 trees). Additional data recorded for each tree included species, height, diameter at $1.3 \mathrm{~m}(\mathrm{dbh})$, leader growth in 1995 and 1996, origin (planted or natural regeneration), and tree health.

In October 2011, 2997 tagged trees were re-sampled for tree health agents and growth (diameter and height). Causes of death were determined wherever possible including examining for evidence of mycelial fans indicating A. ostoyae infection under the bark at the root collar or on exposed roots. A total of 329 trees were dead. Of these, 207 trees were found to have A. ostoyae. In October 2012, all dead trees with A. ostoyae evidence were sampled by sawing a pair of crosssectional discs from each tree. One disc was collected from the root collar, and the second was taken at $1.3 \mathrm{~m}$ height. If 

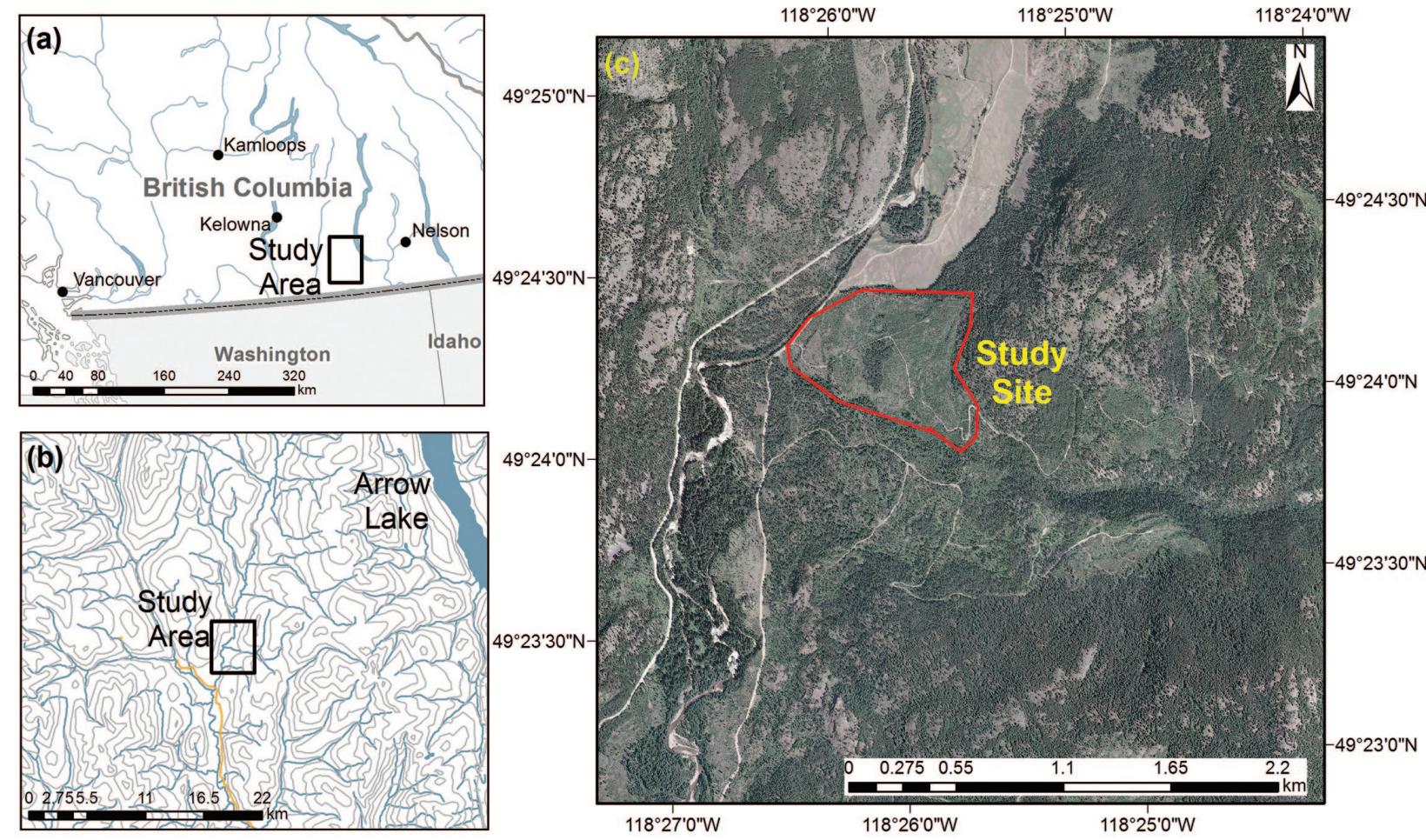

Fig. 1 Knappen Creek study area location near Grand Forks, British Columbia.

the tree was still standing or if the orientation of the tree could be determined, the north aspect of each disc was marked to aid in subsequent comparative assessment of growth rings among disc pairs. Increment core samples were collected from live healthy trees with no above-ground symptoms or signs of infection. These tree samples were used for examining potential influences of weather and for calculating a radial growth index. Three trees of each species were randomly sampled per plot by extracting increment cores at $1.3 \mathrm{~m}$ height. Our sample consisted of 28 western larch, 33 lodgepole pine, and 40 Douglas-fir.

\section{Lab methods}

Increment cores (healthy trees) and cross-sections (dead trees) were mounted, labeled, and sanded to a fine polish (400 grit sandpaper) to reveal individual tracheids and boundaries between annual growth rings (Speer 2010). Cross-sections were scanned using a flat-bed scanner at a minimum of 1200 dpi and measured using CooRecorder 7.6 (Cybis Elektronik 2013). Basal cross-sections were characterized by asymmetrical ring patterning, therefore four radii measurements were made on each sample. The first measurement was along the radius that showed the most restriction in the outermost rings and the other three radii were positioned at $90^{\circ}, 180^{\circ}$, and $270^{\circ}$ from the measurement. In some cases, due to wood decay or degraded samples it was not possible to obtain four radii per sample. The $1.3 \mathrm{~m}$ height cross-sections were symmetrical; thus, a single measurement was taken. If the north face was known, the measurement was along the radius in the same direction as the first radius measured from the basal cross-section where the most recent growth was restricted. If the north face was unknown, the measurement on the $1.3 \mathrm{~m}$ cross-section was taken along the radius that showed the most restriction in the outermost rings. Tree rings from core samples were measured with a computerized system consisting of a stereo zoom microscope (3.5-45 x), velmex sliding digital stage with encoder, video monitor, and laptop computer. The software, MeasureJ2X (Voortech 2010), recorded ring measurements to $0.01 \mathrm{~mm}$ precision.

To ensure correct calendar years were assigned to each growth ring, cross-dating was performed on all samples. We used the skeleton plot method (Stokes and Smiley 1996) generated by CDendro based on Cropper (1979). Two chronologies were developed based on two separate collections of trees (healthy and dead). The healthy tree chronology was free of irregular growth perturbations caused by A. ostoyae. Thus, each dead tree was cross-dated to the live tree chronology (by species) because it lacked this noise. After assigning dates, accuracy was further verified by cross-referencing each tree with its historic field survey records. Where disagreements of $>1$ year occurred between skeleton plot and field survey records, the tree series was discarded and not used for subsequent date-dependent analyses in this study. Date agreements within one year were assigned the skeleton plot date. The final live and dead tree master chronologies were examined for overall cross-dating quality between all trees (a final measure of agreement). This was determined by calculating tree series inter-correlation coefficients using two separate correlation measures. A parametric algorithm based on proportion of last two year's growth (P2YrsL) was applied (Cybis 
2013). Additionally, the nonparametric Gleichlaufigkeit score was derived from the mean percentage of cross-dated ring width intervals sharing the same growth trend increasing or decreasing compared to the previous year (Schweingruber 1988).

To remove both tree size and stand dynamics influence we standardized individual tree series using a negative exponential curve in the software program ARSTAN (Cook and Holmes 1986). A stationary growth index is created by computing biweight robust mean from each standardized series in the live chronology that spans 1997-2012. The resultant annual index values are unitless with a stable variance and mean of 1.0. Thus, any annual index value less than 1.0 indicates a negative departure from average radial growth for the given year, whereas values above 1.0 signify above average growth.

Dating the onset of A. ostoyae infections often relies on excavating complete root systems and thoroughly examining (Cruickshank et al. 2006). Such painstaking effort (Shaw and Kile 1991) may be beyond the capabilities of many researchers. In this study, the vast majority of below-ground root segments were previously lost to biodegradation, thus examining root systems was not an option. Alternatively, we used basal stem sections to search for traumatic resin ducts as a likely indicator of the early infection stage associated with A. ostoyae (Cruickshank et al. 2006; Morrison 2011). In our samples, traumatic resin ducts were consistently found at the onset of periods of reduced radial ring widths on Douglas-fir exhibiting a $50 \%$ or greater reduction in comparison to the growth interval that pre-dated the traumatic resinosus (Fig. 2). This perturbation is symptomatic of A. ostoyae infection in young trees (Cruickshank 2002). Basal area increment growth associated with Armillaria infection is typically reduced 19-43\% (Mallett and Volney 1999; Westwood et al. 2012). Traumatic resinosus was absent on many larch and most lodgepole pine, thus we relied on ring patterns $(>50 \%$ reduced width) as the indicator on these samples. The assigned calendar year represents the onset of significantly reduced radial growth we define as RGO (reduced growth onset). This is not necessarily the first year of colonization of

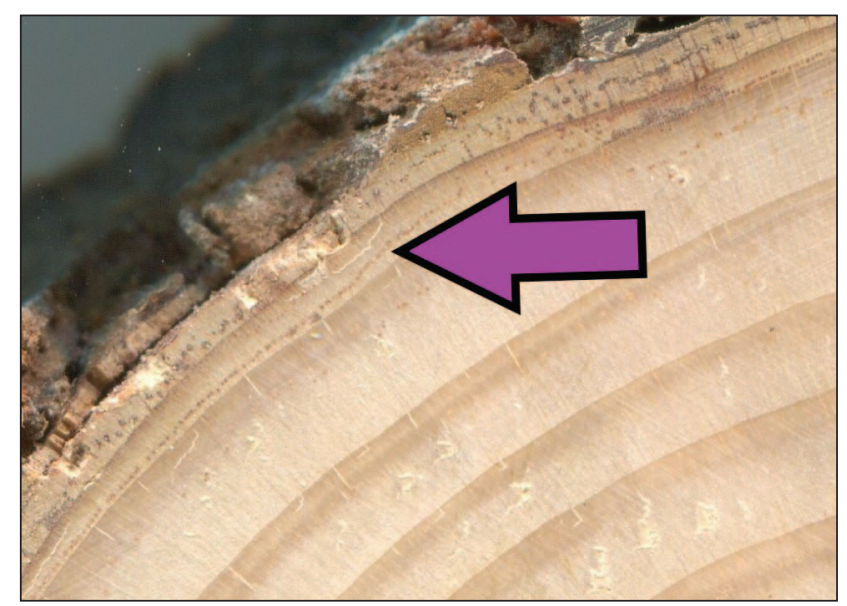

Fig. 2 Traumatic resin ducts and reduced radial growth evident on a young Douglas-fir tree with $A$. ostoyae sampled in the Knappen Creek study area.
A. ostoyae onto the tree's root system. Initially, minor infections restricted to distal root segments may not reliably produce traumatic resinosus in basal samples during their first year (Cruickshank et al. 2006). Thus, RGO serves best to describe the deleterious phase of infection-curtailment of growth, and serves as an estimate of the actual colonization. In all our infected samples, RGO continued uninterrupted until death. Periods of reduced radial growth can be related to other influences besides Armillaria, especially weather. Therefore, isolating A. ostoyae associated ring growth patterns from weather patterns would be prudent. This procedure would entail subtracting a non-host ring chronology from the host species chronology (Swetnam et al. 1985). Because A. ostoyae infects all common tree species in southeastern British Columbia (Cleary et al. 2008), we were challenged by the absence of a non-host. A frequent occurrence of RGO in our live trees would therefore indicate impacts by climate, other growth reducing perturbations, A. ostoyae (with no above-ground evidence) or a combination in synchrony. Only two live series out of 101 exhibited RGO. Unlike all dead trees, RGO in the two live trees was not followed by consecutive years of reduced growth. Examinations of our dead series also included the $1.3 \mathrm{~m}$ cross-sections because they showed more obvious reduction in growth than the basal cross-sections in agreement with Cruickshank (2002) but lacked the signs of traumatic resinosus. Thus, we examined each pair of discs to best capture a more complete estimation of the timing of infection.

\section{Dendroclimatological analysis}

We collected monthly data values for the period 1990-2012 from the nearest weather station (Nicoll), located $15 \mathrm{~km}$ north of the study site (BC WMB 2013). Most winter data were not recorded by this station resulting in an overall record gap of $41 \%$. Thus, missing data were estimated using corresponding values from three neighbouring year-round weather stations within $60 \mathrm{~km}$ (Environment Canada 2013). For gaps in precipitation data, we applied a multiple regression with least absolute deviations criteria (Eischeid et al. 1995). For monthly mean temperatures, a constant ratio was applied (UK traditional method) (Xia et al. 1999). The data from these stations correlated well with data from Nicoll (Pearson $r=0.826-0.870, P<0.01$ ). Two daily drought indices were output from the Nicoll station for the growing season (Turner and Lawson, 1978; Van Wagner 1987). The "duff moisture" code is a numerical rating pertaining to moisture content within $10 \mathrm{~cm}$ of ground surface. It is a function of a series of calculations based on relative humidity, rainfall, daylength, and temperature. The "drought code" represents moisture in the deeper organic layers and is based on calculations of temperature, daylength, and rainfall. High code values indicate low moisture. To identify potentially important weather variables affecting tree growth we applied response function analysis. The standardized healthy tree ring residual chronology (autocorrelation removed) for each species was compared with average monthly value coefficients (precipitation, temperature, duff moisture and drought code). To reduce collinearity, a principal component analysis was applied to get orthogonal transferred predictors. This was performed with the software program DendroClim2002 which uses bootstrapped confidence intervals 
to estimate the significance of each of our coefficients (Biondi and Waikul 2004).

A separate analysis was performed to examine potential influence of weather on the timing of tree mortality. We employed a repeated measure logistic regression model to analyze the annual proportion of infected trees that died adjusting for the covariates including: number of live infected trees per plot, total number of live infected trees (summed among all plots), and annual growth index of healthy trees. All covariates were selected based on our estimation of what may be the most likely factors associated with tree deaths and are re-calculated for each year. The number of infected trees in any given year was estimated based on the total number of living trees that had RGO in their ring series. The following weather variables were modeled according to current $(t)$ and previous year $(t-1)$ values: average summer temperature, average summer drought code, and average summer duff moisture code. Based on RGO dating, we estimated the number of live infected trees on every plot for each of 11 years between 2000 and 2010. Plots were considered to be a random factor in the model and all covariates were considered to be continuous variables. In order to test whether there were any significant differences in the numbers of trees that died according to year, it was necessary to treat this variable as a categorical (noncontinuous) factor in a separate model. Analyses were carried out using the Glimmix procedure in $\mathrm{SAS}^{\circledR}$ statistical software version 9.4. To assess goodness of fit we compared models with the generalized chi-square where lower scores suggest better fit. The term assessing the fit when random effects are present is "Gener Chi-Square/DF" as this measures the degree of over-dispersion in the model. A value of 1.0 suggests no over-dispersion and the model fits the data well.

Years of consistent high or low ring growth were used to indicate pointer years. The calculation of pointer years is a process that identifies calendar years where strong weather influences may have affected a large proportion of sampled trees. To be considered a pointer year, at least $80 \%$ of sampled trees must share the improved or reduced growth (Schweingruber et al. 1990).

\section{Results}

Reduced growth onset and mortality

From the 207 dead trees infected with $A$. ostoyae, 53 were heavily damaged by wood boring insects or rot and thus omitted. An additional 57 trees did not cross-date to within a single year of our original date estimate. Thus, a total of 97 trees were used for analysis: Douglas-fir (46), larch (17), and lodgepole pine (34). Mean series inter-correlations of growth rings were $0.56 \%$ (parametric) and $67 \%$ (nonparametric) indicating agreement in yearly growth.

The first RGO was evident in 1999 with mortality beginning in 2000 (Fig. 3). The number of new RGOs peaked in 2006 followed by a steady decline. Mortality levels peaked in 2007 followed by a healthy trees. decreasing mortality trend until the end of the record. A large number (41\%) of deaths occurred during 2007-2008. The average number of years from initial RGO to death was 2.3 (Douglas-fir), 3.6 (larch), and 2.7 (lodgepole pine) with standard deviations of 2.6, 2.6, 2.7 respectively.

The number of infected trees per species in any given year varied. The within-species proportion of tree mortality associated with A. ostoyae between 1991 and 2012 was: Douglasfir (15.3\%), western larch (7.4\%), and lodgepole pine (3.7\%). Additionally, the percentage of infected trees that died each year varied according to species (Fig. 4). During 2007 and 2008, most of the infected lodgepole pine died. During 2003 and 2009 notably higher proportions of infected Douglas-fir died. However, during this time period (2001-2009), the annual mortality did not vary significantly with species $(F=1.75, P=0.20)$ or year $(F=1.37, P=0.28)$.

\section{Radial growth of healthy trees}

Radial growth was most reduced in 2002-2003, 2007-2008 and 2012 (Fig. 3). The ring-width chronology had very strong series inter-correlations of 0.68 (parametric) and 0.74 (nonparametric) indicating similar growth trends among species. The mean tree ring width sensitivity within healthy trees was 0.21 (Douglas-fir), 0.26 (larch), and 0.20 (lodgepole pine). These values are within the expected range for adequately reflecting response of trees to annual climatic fluctuations in the region (Lo et al. 2010). Based on examination of live healthy regeneration, a total of seven pointer years were detected (Fig. 3). For negative growth pointer years (2002, $2006,2007,2012$ ), an indication of reduced growth, only 2007 corresponded with high mortality of infected trees. Similarly, pointer years were not consistent with the frequencies of RGO. Response function analysis indicated that average monthly temperatures were related to radial growth. Douglas-fir responded positively to higher temperatures in

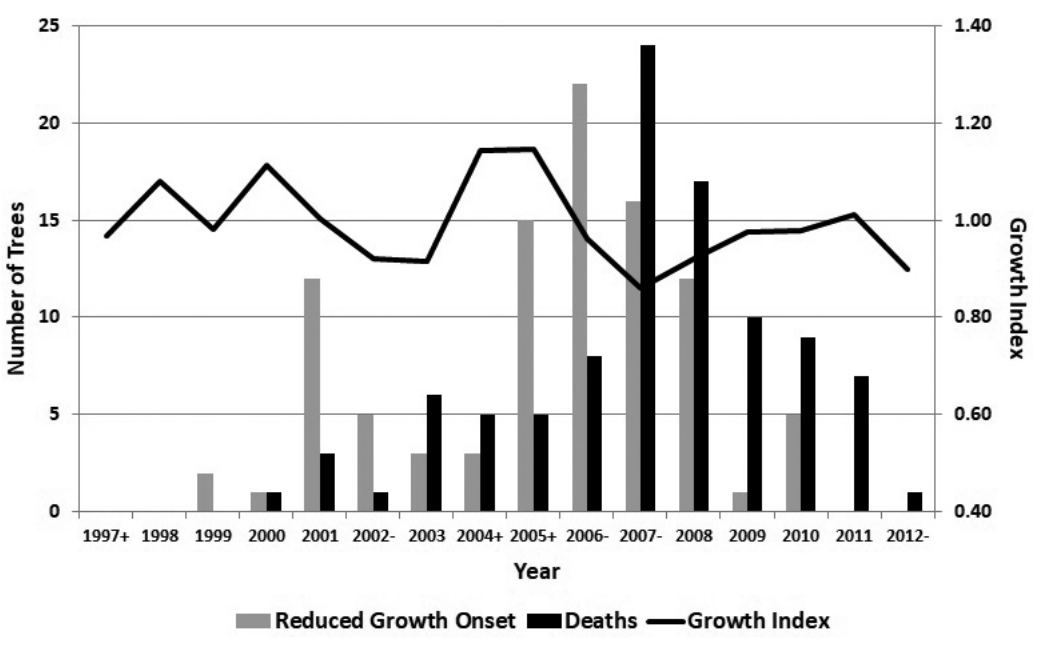

Fig. 3 Dates associated with reduced growth onset (RGO) and deaths of trees infected with $A$. ostoyae. Residual radial growth index of the healthy regeneration cohort. Six pointer years indicate widespread positive $[+]$ or negative (-) radial growth among 


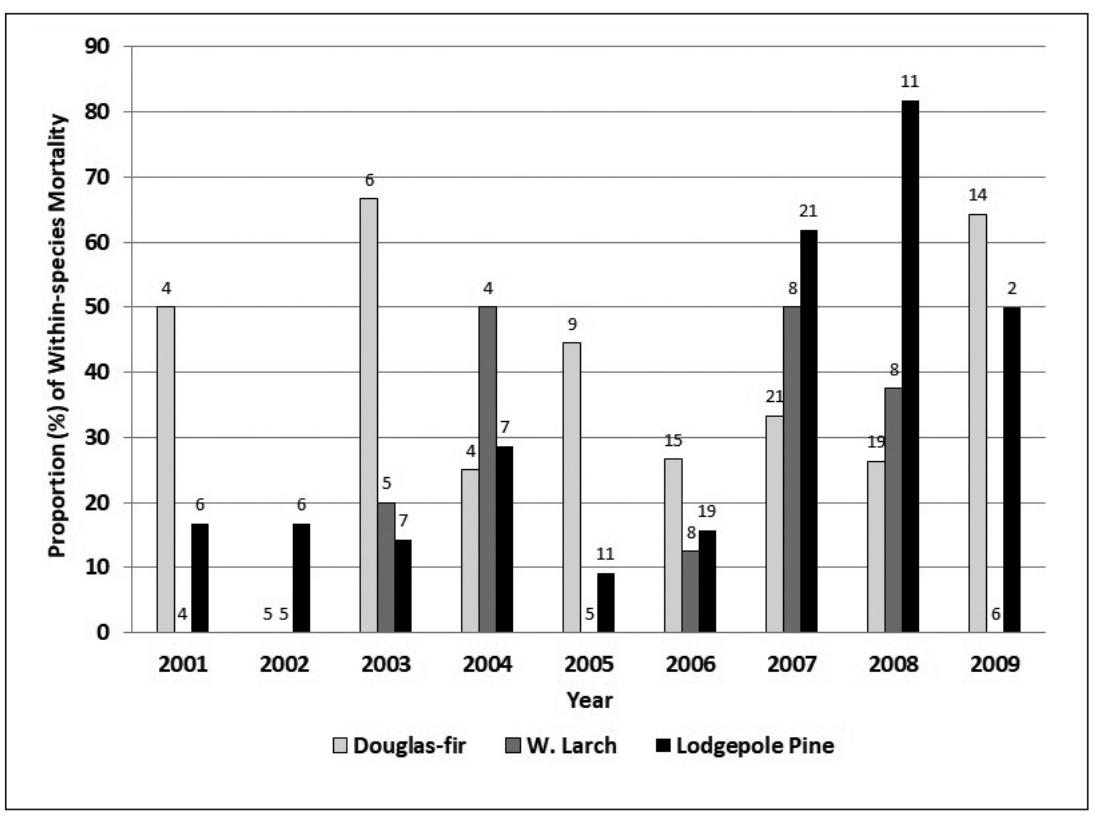

Fig. 4 Percentage of infected trees that died each year within species based on total number of infected trees (column labels).

February $(r c=0.30)$. Larch and lodgepole pine growth were increased by previous year higher October temperatures $(r c=$ 0.27 and 0.28 , respectively). No other climatic variables were significant at a 0.05 level.

\section{Annual mortality factors}

The logistic regression analysis required two separate model runs. These were not combined into a stepwise model because: 1) stepwise modeling is highly dependent on sample order; and, 2) the 11-year period requires input variables repeated at each plot every 11 years. Our analysis indicates that statistically significant effects on tree mortality numbers were experienced during the focus period (2000-2010) (Table 1). Drought codes (current and previous year) and duff moisture codes (previous year) were significant factors (model 1). Growth index and the number of infected trees within each plot were also found to be statistically significant at $\mathrm{P}<0.01$ and $\mathrm{P}<0.05$, respectively, in predicting mortality. Summer temperatures were not found to be a significant factor. Model 1 indicates a good fit (general chi-square / DF = 1.26). Our analysis also showed a statistically significant difference in the mean proportions of mortality between years (model 2). In comparing years, post-hoc testing revealed a single year $(2007)$ had a significantly different mean $(\mathrm{P}<0.01)$ from each other year. This model indicates a good fit (general chi-square / $\mathrm{DF}=1.27$ ).

\section{Discussion}

By applying standard dendrochronological methods, we were able to examine a fine level of resolution (annual) for estimating infection and death rates of trees associated with A. ostoyae. This examination is the only study we are aware of that reports how mortality associated with infected trees can differ significantly between years during the early period of plantation establishment (Table 1). Beginning 2000, yearly mortality slowly increased until a pronounced spike occurred in 2007-2008 (Fig. 3). Infected trees in all but three of 14 plots experienced mortality these two years. The belowground spread of $A$. ostoyae is not known to be epidemical where large numbers of hosts become infected and die within a time window of several years or less. Instead, owing to the gradual growth of rhizomorphs and roots, $A$. ostoyae spread may not exceed much more than 1-1.3 m/yr within tree plantations of the Pacific Northwest (Shaw and Roth 1976; Peet et al. 1996). Thus, exogenous factors including environment and its influence on the infected host are likely associated with a pulse of mortality during 2007-2008.

We conclude that drought had a role in the mortality of many infected trees. The numbers of living infected trees were at their peak immediately preceding 2007, thereby providing a large pool of individuals highly vulnerable to mortality. This at least partially explains the high mortality rate. However, regression analysis indicates drought codes (current and previous year) and duff moisture codes (previous year) are more compelling factors affecting mortality than simply the number of infected trees during the year of death (Table 1). Defense mechanisms that healthy host trees employ against root disease include production of chemical compounds, resinosus, and formation of callus and cork barriers. Trees suffering physiological drought stress can be impaired in their ability to effectively produce such defences (Kolb et al. 2016). The years 2003 and 2007 were the two driest years in our weather station's

Table 1 Logistic regression models of the annual proportions of dead trees with variables: year (2000-2010), number of live infected trees (summed among all plots), number of live infected trees per plot, current year and previous year (PY) values, drought code (DC), duff moisture code (DMC), and growth index (annual radial growth index of healthy trees)

\begin{tabular}{lrr}
\hline Effect & F Value & Pr $>$ F \\
\hline Model 1 & & \\
Year & 13.15 & 0.0004 \\
No._Infected_Live_Trees & 2.48 & 0.1165 \\
No._Infected_Live_Plots & 3.94 & 0.0485 \\
Avg._Summer_Temp & 0.76 & 0.3858 \\
Avg._Summer_DC & 21.20 & $<.0001$ \\
Avg._Summer_DMC & 0.85 & 0.3589 \\
PY_Summer_Temp & 2.67 & 0.1035 \\
PY_Summer_DC & 7.88 & 0.0055 \\
PY_Summer_DMC & 7.35 & 0.0073 \\
Growth_Index & 19.24 & $<.0001$
\end{tabular}

$\begin{array}{lll}\text { Model 2 } & & \\ \text { Year } & 7.79 & <.0001 \\ \text { No_Infected_Live_Plot } & 3.90 & 0.0496\end{array}$


recording period (1978-2012) mirroring region-wide summer droughts (NOAA 2003, 2007). Dempster (2017) remarked that incidence of $A$. ostoyae and mortality of juvenile lodgepole pine were related to increases in potential evapotranspiration with the proportion of infected trees corresponding to higher summer heat-moisture index values in addition to other climate variables. Morrison (2011) noted peaks in mortality of infected trees immediately following drought years but did not investigate any potential relationship. Drought is commonly implicated in Armillaria associated mortality of mature conifers (Wargo and Harrington 1991). All conifers in southern BC are susceptible hosts to $A$. ostoyae. However, Cleary et al. (2008) suggest resistance levels increase differentially according to host species as trees gain age. After about 20 years, they found that Douglas-fir ranked highest in susceptibility, followed by lodgepole pine and larch. Our findings suggest that Douglas-fir may be most susceptible starting at an earlier age than 20 .

Periods of reduced ring growth and RGO immediately preceding death are strongly inferred to be associated with $A$. ostoyae. Signs of this pathogen were physically observed on all 97 dead trees analyzed. However, because we did not discriminate the climate signal from these infection periods, we cannot quantify the relative contribution of each to reducing ring growth. Our results are consistent with previous investigations that examined the time interval between onset of A. ostoyae infection and death of individual young trees. Morrison and Pellow (1994) and Morrison (2011) described intervals averaging between $1-3$ years, which are similar to our findings (2.3-3.6 years). In older trees, however, the time between infection and death likely extends to 20 years or more (Cherubini et al. 2002; Morrison 2011). It's evident that plantation trees in our study experienced a distinct wave of impact. At 21 years of age, our overall loss of trees to $A$. ostoyae infection was approximately $6.4 \%$. Findings from other studies in the region indicate a range of $3 \%$ to $14.8 \%$ mortality associated with Armillaria in plantation ages 14 to 19 years (Morrison et al. 1988; Morrison 2011). Mortality began nine years after the initial planting, peaked at 16-17 years, and was much reduced by 21 years. A similar bellshape curve has been reported by Morrison and Pellow (1994) where mortality peaked at 10 years. Peet et al. (1996) documented peaks in the number of infected trees at 14 and 19 years for two plantations. Both of these studies indicated peaks were followed by a less pronounced decreasing trend extending to plantation ages of 22-27 years. Our findings indicate a slightly later onset of mortality compared to Morrison and Pellow (1994) and Morrison (2011) where deaths were observed to commence at 5-6 years after planting. The timing of this surge has relevance to forest management in $\mathrm{BC}$ where public lands are mandated to meet minimum reforestation stocking standards (BC FRPA 2004). To gauge success, plantations are evaluated under a "free growing" assessment framework, on average, nine years after planting in the southern interior (BC FLNRORD 2009). Because mortality levels typically do not peak until after nine years, these evaluations may not be capturing a significant period of mortality inherent to the widespread ICH zone. Considering the primary agent of mortality in young plantations of the ICH is Armillaria (Nevill et al. 1996; Cruickshank 2017), Woods and Coates (2013) recommend closer regulatory monitoring of tree regeneration. Conducting stocking surveys at least 15-20 years after planting could improve the evaluation of plantation success in the ICH zone.

Our tree ring growth index curve corresponded well with higher mortality in 2003 and 2007-2008 (Fig. 3) and with our mortality model (Table 1). In contrast, our application of growth pointer years did not closely accord with years of heavy mortality. Identifying pointer years may be useful for explaining general trajectories of growth (positive or negative) but unlike radial growth index, cannot represent the magnitude of growth trend.

Summer drought episodes are predicted to increase in frequency and intensity in the region (Murdock and Werner 2011). Because A. ostoyae is often associated with stressed trees (Hadfield et al. 1986; Cleary 2007), both infection and mortality rates are likely to increase if current climate trends continue (Klopfenstein et al. 2009). As plantation trees advance in age, mortality rates attributed to $A$. ostoyae appear to decrease for most host species (Robinson and Morrison 2001; Cleary et al. 2008). Whereas many older infected trees (ca. 20+ years) may survive under favourable climates, an increased frequency of drought-driven stress may lead to elevated mortality associated with this root disease. We therefore recommend placing emphasis on monitoring plantations of early-mid rotation ages, especially in drought-prone locations.

\section{Acknowledgements}

Our gratitude to those who provided helpful input and feedback: Jodi Axelson and Peter Ott (BC Ministry of Forests, Lands, Natural Resource Operations and Rural Development), Ian Bercovitz (Simon Fraser University), Mike Cruickshank (Canadian Forest Service), Lars-Åke Larsson (CDendro software), and Kathy Lewis (University of Northern BC). Our two anonymous reviewers provided very helpful feedback. This research was funded in full by the British Columbia Ministry of Forests, Lands, Natural Resource Operations and Rural Development.

\section{References}

BC FLNRORD. 2009. (British Columbia Ministry of Forests, Lands, Natural Resource Operations and Rural Development). Silviculture survey procedures manual: stocking and free growing survey. Available from https:/www.for.gov.bc.ca/hfp/publications/ 00099/Surveys/Silviculture\%20Survey\%20Procedures\%20ManualApril\%201\%202009.pdf [Accessed 30 March 2020].

BC FRPA. 2004. (British Columbia Forest and Range Practices Act). Available from http://www.bclaws.ca/Recon/document/ ID/freeside/00_02069_01 [Accessed 30 January 2020].

BC WMB. 2013. (British Columbia Wildfire Management Branch). Daily Fire Weather Data. Available from https://www.pacificclimate.org/data/bc-station-data [Accessed 30 January 2020].

Biondi, F. and J. Waikul. 2004. DENDROCLIM2002: A C++ program for statistical calibration of climate signals in tree-ring chronologies. Comp. Geosci. 30:303-311. https://doi.org/10.1016/ j.cageo.2003.11.004.

Chapman, W.K., B. Schellenberg and T. Newsome. 2011. Assessment of Armillaria root disease infection in stands in south-central British Columbia with varying levels of overstory retention, with and without pushover logging. Can. J. For. Res. 41(8):1598-1605. https://doi.org/10.1139/x11-085.

Cherubini, P., G. Fontana, D. Rigling, M. Dobbertin, P. Brang and J.L. Innes. 2002. Tree-life history prior to death. Two fungal 
root pathogens affect tree-ring growth differently. J. Ecol. 90:839850. https://doi.org/10.1046/j.1365-2745.2002.00715.x.

Cleary, M.R. 2007. Host responses in Douglas-fir, western hemlock and western redcedar to infection by Armillaria ostoyae and Armillaria sinapina. PhD thesis. University of British Columbia, Vancouver, B.C.

Cleary, M., B. van der Kamp and D. Morrison. 2008. British Columbia's southern interior forests. Armillaria root disease stand establishment decision aid. BC J. Ecosyst. Manag. 9(2):60-65.

Cook, E.R. and R. Holmes. 1986. Guide for Computer Program ARSTAN. Laboratory of Tree-Ring Research. University of Arizona, Tucson, AR.

Cropper, J.P. 1979. Tree-ring skeleton plotting by computer. Treering Bull. 39:47-59.

Cruickshank, M. 2000. Volume loss of Douglas-fir infected with Armillaria ostoyae. In: C. Hollstedt, K. Sutherland and T. Innes (Eds.): Proceedings, from Science to Management and Back. A Science Forum for Southern Interior Ecosystems of British Columbia, Kamloops, BC. December 1-2, 1999. Southern Interior Forest Extension and Research Partnership. pp. 127-129.

Cruickshank, M.G. 2002. Accuracy and precision of measuring cross-sectional area in stem disks of Douglas-fir infected by Armillaria root disease. Can. J. For. Res. 32:1542-1547. https://doi.org/ 10.1139/x02-074.

Cruickshank, M.G. 2017. Climate and site factors affecting survival and yield of Douglas-fir in the Cedar-Hemlock ecosystem of the southern interior of British Columbia. Forestry 2017 (90): 219-233. https://doi.org/10.1093/forestry/cpw040.

Cruickshank, M. G., D. Lejour and D.J. Morrison. 2006. Traumatic resin canals as markers of infection events in Douglas-fir roots infected with Armillaria root disease. For. Pathol. 36:372-384. https://doi.org/10.1111/j.1439-0329.2006.00469.x.

Cybis Elektronik 2013. CDendro and CooRecorder. Available from http://www.cybis.se/forfun/dendro/ [Accessed 30 January 2020].

Dempster, W.R. 2017. Impact of climate on juvenile mortality and Armillaria root disease in lodgepole pine. For. Chron. 93(2):148160. https://doi.org/10.5558/tfc2017-021.

Dukes, J.S., J. Pontius, D. Orwig, J.R. Garnas, V.L. Rodgers, N. Brazee, B.J. Cooke, K.A. Theoharides, E.E. Strange, R. Harrington, J. Ehrenfeld, J. Gurevitch, M. Lerdau, K. Stinson, R. Wick, and M.P. Ayres. 2009. Responses of insect pests, pathogens, and invasive plant species to climate change in the forests of northeastern North America: What can we predict? Can. J. For. Res. 39(2):231-248. https://doi.org/10.1139/X08-171.

Edmonds, R.L., J.K. Agee and R.I. Gara. 2010. Forest Health and Protection. (2nd ed.). Long Grove, IL. Waveland Press. 667 pp.

Eischeid, J.K., C.B. Baker, T.R. Karl, and H.F. Diaz. 1995. The quality control of long-term climatological data using objective data analysis. Journal of Applied Meteorology 34:2787-2795. https://doi.org/10.1175/1520-0450(1995)034<2787:TQCOLT> 2.0.CO;2.

Environment Canada 2013. National Climate Data and Information Archive. Available from http://climate.weather.gc.ca/historical_data/search_historic_data_e.html. [Accessed 30 January 2020].

Hadfield, J.S., D.J. Goheen, G.M. Filip, C.L. Schmitt and R.K. Harvey. 1986. Root diseases in Oregon and Washington conifers. US For. Serv. R6-FPM-250-86, Portland, OR.

Kliejunas, J.T. 2011. A risk assessment of climate change and the impact of forest diseases on forest ecosystems in the Western United States and Canada. Gen. Tech. Rep. PSW-GTR-236. Albany, CA. U.S. Department of Agriculture, Forest Service, Pacific Southwest Research Station. https://doi.org/10.2737/PSW-GTR-236.

Kolb, T.E., C J. Fettig, M.P. Ayres, B.J. Bentz, J.A. Hicke, R. Mathiasen, J.E. Stewart, A.S. Weed. 2016. Observed and anticipated impacts of drought on forest insects and diseases in the United States. For. Ecol. and Mgt. 380:321-334. https://doi.org/10.1016/ j.foreco.2016.04.051.
Klopfenstein, N. B., M-S. Kim, J.W. Hanna, B.A. Richardson and J.E. Lundquist. 2009. Approaches to predicting potential impacts of climate change on forest disease: An example with Armillaria root disease. Res. Pap. RMRS-RP-76. Fort Collins, CO. U.S. Department of Agriculture, Forest Service, Rocky Mountain Research Station. 10 p. https://doi.org/10.2737/RMRS-RP-76.

Lo, Y., J.A. Blanco, B. Seely, J.P. Welham, and J.P. Kimmins. 2010. Relationships between climate and tree radial growth in interior British Columbia, Canada. For. Ecol. and Mgt. 259:932-942. https://doi.org/10.1016/j.foreco.2009.11.033.

MacKillop, D.J. and A.J. Ehman. 2016. A field guide to site classification and identification for southeast British Columbia. The south-central Columbia Mountains. Prov. B.C., Victoria, B.C. Land Manag. Handb. 70.

Mallett, K.I. and W.J.A. Volney. 1999. The effect of Armillaria root disease on lodgepole pine tree growth. Can. J. For. Res.: 29(2): 252 259. https://doi.org/10.1139/x98-203.

Morrison, D.J. 2000. Armillaria root disease. A major impediment to sustainable management of southern interior ecosystems. In: C. Hollstedt, K. Sutherland and T. Innes (Eds.): Proceedings, from Science to Management and Back. A Science Forum for Southern Interior Ecosystems of British Columbia, Kamloops, BC. December 1-2, 1999. Southern Interior Forest Extension and Research Partnership. pp. 23-26.

Morrison, D.J. 2011. Epidemiology of Armillaria root disease in Douglas-fir plantations in the cedar-hemlock zone of the southern interior of British Columbia. For. Pathol. 41:31-40. https://doi.org/ 10.1111/j.1439-0329.2009.00630.x.

Morrison, D.J. and K. Pellow. 1994. Development of Armillaria root disease in a 25-year old Douglas-fir plantation. In M. Johansson and J. Stenlid (Eds.): Proceedings of the Eighth International Conference on Root and Butt rots. August 9-16, 1993. Wik, Sweden Haikko, Finland. Uppsala, Sweden. Swedish University of Agricultural Sciences. pp. 560-571.

Morrison, D.J., G.W. Wallis, and L.C. Weir. 1988. Control of Armillaria and Phellinus root diseases. 20-year results from the Skimikin stump removal experiment. Information Report BC-X302. Victoria, BC. Canadian Forest Service, Pacific Forestry Centre. Morrison, D.J, M. Cruickshank and M.G. Lalumiere. 2014. Control of laminated and Armillaria root diseases by stump removal and tree species mixtures: Amount and cause of mortality and impact on yield after 40 years. Forest Ecology and Management 319 (2014):7598. https://doi.org/10.1016/j.foreco.2014.02.007.

Morrison, D.J., K.W. Pellow, A.F.L. Nemec, D.J. Norris and P. Semenoff. 2001. Effects of selective cutting on the epidemiology of Armillaria root disease in the southern interior of British Columbia. Can. J. For. Res. 31:59-70. https://doi.org/10.1139/x00-144.

Murdock, T.Q. and A.T. Werner. 2011. Canadian Columbia Basin Climate Trends and Projections: 2007-2010 Update. Pacific Climate Impacts Consortium, University of Victoria, Victoria, BC.

Nevill, R., N. Humphreys, and A. Van Sickle. 1996. Five-year overview of forest health surveys in young managed stands in British Columbia, 1991-1995. FRDA Report ISSN 0835-0752, no. 262.

NOAA 2003. National Centers for Environmental Information, State of the Climate. Drought for Annual 2003, published online January 2004. Available from http.//www.ncdc.noaa.gov/sotc/ drought/200313 [Accessed 30 January 2020].

NOAA 2007. National Centers for Environmental Information, State of the Climate. Drought for Annual 2007, published online January 2004. Available from http.//www.ncdc.noaa.gov/sotc/ drought/200713 [Accessed 30 January 2020].

Peet, F.G., D.J. Morrison and K.W. Pellow. 1996. Rate of spread of Armillaria ostoyae in two Douglas-fir plantations in the southern interior of British Columbia. Can. J. For. Res 26:148-151. https://doi.org/10.1139/x26-016.

Robinson, R.M. and D.J. Morrison. 2001. Lesion formation and host response to infection by Armillaria ostoyae in the roots of west- 
ern larch and Douglas-fir. For. Path.31:371-385. https://doi.org/ 10.1046/j.1439-0329.2001.00260.x.

Ross-Davis, A.L. J.W. Hanna, M. Kim N.B. Klopfenstein. 2012. Advances toward DNA-based identification and phylogeny of North American Armillaria species using elongation factor-1 alpha gene. Mycoscience (2012) 53:161-165. https://doi.org/10.1007/ S10267-011-0148-X.

Schweingruber, F.H. 1988. Tree rings: Basics and applications of dendrochronology. D. Reidel Publishing Co., Dordrecht, the Netherlands.

Schweingruber, F.H., D. Eckstein, F. Serre-Bachet and O.U. Braker. 1990. Identification, presentation and interpretation of event years and pointer years in dendrochronology. Dendrochronologia 8:9-38.

Shaw, C.G. and L.F. Roth. 1976. Persistence and distribution of a clone of Armillaria mellea in a ponderosa pine forest. Phytopathology 66:1210-1213. https://doi.org/10.1094/Phyto-66-1210.

Shaw, C.G. and G.A. Kile. 1991. Armillaria root disease. USDA Forest Service. Agriculture Handbook No. 691.

Siltech. 1989. Root removal survey: Knappen Creek, BC. Unpublished report. Siltech Forestry, LTD.

Speer, J.H. 2010. Fundamentals of tree ring research. University of Arizona Press. 333 pp.

Stokes, M.A. and T.L. Smiley. 1996. An introduction to tree-ring dating. University of Arizona Press. 73 pp.

Swetnam, T.W., M.A. Thompson and E.K. Sutherland. 1985. Using dendrochronology to measure radial growth of defoliated trees. USDA Agricultural Handbook No. 639.
Turner, J.A., and B.D. Lawson. 1978. Weather in the Canadian forest fire danger rating system: A user guide to national standards and practices. BC-X-177, Environment Canada Forestry Service.

Van Wagner, C.E. 1987. Development and structure of the Canadian forest fire weather index system. 1987. Canadian Forestry Service, Headquarters, Ottawa. Forestry Technical Report 35. 35 p.

Voortech 2010. Measure J2X User's Guide. Available from www.voortech.com/projectj2x/docs/ [Accessed 30 January 2020].

Wargo, P.M. and T.C. Harrington. 1991. Host stress and susceptibility. In Armillaria root disease. USDA Forest Service. Agriculture Handbook No. 691. pp. 88-101.

Westwood, A.R., F. Conciatori and K. Knowles. 2012. Effects of Armillaria root disease on the growth of Picea mariana trees in the boreal plains of central Canada. For. Ecol. Manag. 266:1-10. https://doi.org/10.1016/j.foreco.2011.11.005.

Woods, A. and K.D. Coates. 2013. Are biotic disturbance agents challenging basic tenets of growth and yield and sustainable forest management? Forestry 86:543-554. https://doi.org/10.1093/ forestry/cpt026.

Xia, Y., P. Fabian, A. Stohl and M. Winterhalter. 1999. Forest climatology. Estimation of missing values for Bavaria, Germany. Agric. For. Meteorol. 96:131-144. https://doi.org/10.1016/S01681923(99)00056-8. 